\title{
Deciduous Fruit Cultivar Development in Florida
}

The Univ. of Florida, Gainesville, low-chill deciduous fruit improvement program was begun in 1953 by R.H. Sharpe. W.B. Sherman joined the program in 1966, Sharpe retired in 1975, and P.M. Lyrene joined in 1977. The" breeding program was initiated because Florida had the climate and available land to produce the earliest fruit in the United States when competition was nonexistent and prices were likely to be high. The cultivar improvement program consists of clonal evaluation to allow identification of the best existing cultivars and breeding of crops where only poorly adapted or lowquality cultivars exist. The main emphasis was originally, and continues to be, in peach [Prunus persica L. (Batsch)] and blueberry (Vaccinium corymbosum L. and hybrids and $V$. ashei Reade and hybrids) breeding because these crops were deemed to have the most commercial potential. Minor crops such as apricot (Prunus armeniaca L.), apple (Malus domestics Borkh), blackberry (Rubus spp.), sweet cherry (Prunus avium L.), pear (Pyrus spp.), kaki persimmon (Diospryos kaki L.), and Japanese-type plums (Prunus salicina Lindl. and hybrids) have generated small hybrid populations, and clonal evaluations of chance seedlings and cultivars are being made in these and the additional crops of jujube (Zizyphus jujuba Mill.), mayhaw (Crataegus spp.), and pecan [Carya illinoensis (Wangenh.) K. Koch]. Grape ( Vitis spp.) improvement is carried out in a separate breeding program at the Central Florida Research and Education Center at Leesburg.

Apples. 'Anna' and 'Dorsett Golden' were the earliest ripening and among the lowest chilling cultivars from $\approx 200$ tested. Four laterripening, slightly higher-chilling clones are recommended for trial (Miller and Baker, 1982). A small breeding program $(\approx 1000$ seedlings) has yielded five selected genotypes that ripen between 2 weeks earlier and 6 weeks later than 'Anna'. Current objectives are to breed a redskinned cultivar that ripens before 'Anna' and a green-skinned summer apple.

Apricot. About 300 seedlings (three to 10 of each genotype) from reported low-chill apricot genotypes have been tested, but only seed from northern Egypt has given seedlings that flowered as early as other adapted low-chill Prunus. Fruit set has been poor even though flowering appears normal. Attempts

Received for publication 25 July 1990. Florida AgriculturalExperimentStation Journal Series no. R-00966. The cost of publishing this paper was defrayed in part by the payment of page charges. Underpostal regulations, this paper therefore must be hereby marked advertisement solely to indicate this fact. are being made to introgress apricot with diploid Japanese-type plums and $P$. mume (Sieb.) Sieb. and Zucc. to achieve adaptation for fruit set.

Blackberry. The blackberry breeding program was active from the mid-1950s to the mid-1960s, producing two trailing dewberry cultivars (Sherman and Sharpe, 1971). The germplasm was based on crosses of the nessberries (Rubus spp. hybrids) from Texas with local genotypes of Rubus trivialis Michx. Attempts at production for shipping failed in the 1960s because of short shelf life, but home garden and local pick-your-own operations continue. Soluble solids content and yields were not high enough to support a processing industry.

Blueberries. Both highbush (tetraploid, mainly Vaccinium corymbosum L.) and rabbiteye (hexaploid, mainly $V$. ashei Reade) blueberries have been bred in Florida. Highbush blueberries received most of the breeding emphasis between 1950 and 1970 because they offered greater possibilities for producing early-ripening fruit and because the native blueberry species that were abundant in the central Florida peninsula produced better hybrids with $V$. corymbosum than with $V$. ashei (Sharpe, 1954; Sharpe and Darrow, 1959; Sharpe and Sherman, 1971). Highbush cultivars and selections form Michigan were crossed with evergreen $V$. darrowi Camp selections from the Florida peninsula. Even though these were diploid $\times$ tetraploid crosses, the diploid ( $V$. darrowi) produced $2 \mathrm{n}$ gametes frequently enough to allow for recovery of some highly fertile tetraploid hybrids. Rabbiteye $\times V$. darrowi hybrids were also obtained and were included in the starting population from which tetraploid cultivars were obtained by recurrent selection. The tetraploid cultivars Sharpblue, Flordablue, and Avonblue all have pedigrees that include northern highbush cultivars, $V$. ashei, and $V$. darrowi. These were the first tetraploid highbush-type cultivars that could be cultivated successfully in areas with $<600$ annual chill units.

In recent years, several other germplasm sources have been explored to improve adaptation of highbush blueberries in Florida. Vaccinium elliottii Chapmn. (2x) from northcentral Florida, the blue-fruited ( $V$. australe Small) phase of $V$. corymbosum (4x) from southeastern Georgia, the black-fruited ( $V$. fuscatum Ait.) phase of $V$. corymbosum (4x) from northeastern Florida, and $V$. corymbosum (2x) from south-central Florida have all been used in breeding.

Rabbiteye blueberry breeding in Florida has had two main objectives: earlier-ripening cultivars and cultivars that fruit well after mild winters (Lyrene, 1987). Intense selection for earlier ripening has produced selections that ripen in northern Florida $\approx 2$ weeks earlier than standard early cultivars such as 'Climax' and 'Premier'. Early flowering has been a problem with many of these selections. Introgression of genes from $V$. ashei $\times V$. con-

Table 1. Deciduous fruit cultivars released by the Univ. of Florida, Gainesville.

\begin{tabular}{|c|c|c|}
\hline $\begin{array}{l}\text { Crop and } \\
\text { cultivar }\end{array}$ & $\begin{array}{l}\text { Current } \\
\text { status use }\end{array}$ & $\begin{array}{l}\text { Year } \\
\text { released }\end{array}$ \\
\hline \multicolumn{3}{|l|}{$\begin{array}{l}\text { Blackberry } \\
\text { (dewberry) }\end{array}$} \\
\hline Flordagrande & Limited home & 1964 \\
\hline Oklawaha & Limited home & 1966 \\
\hline \multicolumn{3}{|l|}{$\begin{array}{l}\text { Blueberry } \\
\text { (rabbiteye) }\end{array}$} \\
\hline Bluegem & Commercial & 1970 \\
\hline Aliceblue & Limited commercial & 1978 \\
\hline Beckyblue & Commercial & 1978 \\
\hline Bonita & Commercial & 1985 \\
\hline Chaucer & Limited commercial & 1985 \\
\hline Choice & Limited commercial & 1985 \\
\hline Windy & Commercial trial & 1990 \\
\hline Snowflake & Commercial trial & 1990 \\
\hline \multicolumn{3}{|l|}{$\begin{array}{l}\text { Blueberry } \\
\text { (highbush) }\end{array}$} \\
\hline Flordablue & Limited commercial & 1975 \\
\hline Sharpblue & Commercial & 1975 \\
\hline Avonblue & Limited commercial & 1977 \\
\hline Misty & Commercial trial & 1990 \\
\hline Marimba & Commercial & 1990 \\
\hline \multicolumn{3}{|l|}{ Nectarine } \\
\hline Sunred & Home & 1964 \\
\hline Sungold & Home & 1969 \\
\hline Sunrich & Home & 1971 \\
\hline Sunlite & commercial & 1975 \\
\hline Sunripe & Home & 1979 \\
\hline Sunfre $^{2}$ & Commercial & 1982 \\
\hline Sunhome & Home & 1985 \\
\hline Sungem & Commerc & 1986 \\
\hline Sundollar & Commercial trial & 1989 \\
\hline Sunblaze & Commercial trial & 1990 \\
\hline \multicolumn{3}{|l|}{ Peach } \\
\hline Okinawa & Limited rootsto & 1957 \\
\hline Flordahome & Limited borne & 1960 \\
\hline Flordawon & Obsolete & 1961 \\
\hline Flordaqueen & Obsolete & 1961 \\
\hline Flordasun & Limited home & 1964 \\
\hline Flordabelle & Limited home & 1970 \\
\hline Flordared & Obsolete & 1970 \\
\hline Flordagold & Commercial & 1976 \\
\hline Flordaking & Commercial & 1978 \\
\hline Flordaprince & Limited commercial & 1982 \\
\hline \multicolumn{2}{|c|}{ FlordaGrande ${ }^{y}$ Limited commercial } & 1985 \\
\hline TropicSweet ${ }^{y}$ & Limited commercial & 1986 \\
\hline Flordacrest & Commerc & 1988 \\
\hline Flordaglo & Limited commercial & 1988 \\
\hline Flordastar & Limited commercial & 1988 \\
\hline \multicolumn{2}{|c|}{ TropicBeauty ${ }^{y}$ Commercial } & 1988 \\
\hline TropicSnowy & Limited commercial & 1988 \\
\hline Flordadawn & Commercial trial & 1989 \\
\hline Flordaglobe & Commercial trial & 1989 \\
\hline Oro $A^{x}$ & Germplasm/home & 1989 \\
\hline Flordaguard & Rootstock trial & 1990 \\
\hline \multicolumn{3}{|l|}{ Pear } \\
\hline Flordahome & Home & 1982 \\
\hline \multicolumn{3}{|l|}{ Pecan } \\
\hline Moreland" & Commercial & 1989 \\
\hline
\end{tabular}

${ }^{2}$ Joint release with U.S. Dept. of Agriculture, Fresno, Calif.

'Joint release with Texas Agricultural Experiment Station, Weslaco.

${ }^{\mathrm{J}}$ Joint release with Collegio de Postgraduados, Chapingo, Mexico.

"Joint release with Louisiana Agricultural Experiment Station, Baton Rouge. 